\title{
ELIMINASI SCHISTOSOMIASIS DI SULAWESI TENGAH; REVIEW SISTEMATIK DAN FOKUS GROUP DISCUSSION
}

\author{
Pitriani $^{1}$, Muh. Jusman Rau ${ }^{2}$ \\ ${ }^{1}$ Peminatan Kesehatan Lingkungan, Fakultas Kedokteran dan Ilmu Kesehatan Universitas Tadualko \\ pitrianiarifin@yahoo.co.id \\ ${ }^{2}$ Peminatan Epidemiologi, Fakultas Kedokteran dan Ilmu Kesehatan Universitas Tadualko \\ jusman_epid06@yahoo.com
}

\begin{abstract}
ABSTRAK
Pengawasan dan pengendalian Schistosomiasis merupakan prioritas masalah kesehatan masyarakat di Sulawesi Tengah. Penelitian tunggal tidaklah cukup mendasari pengambilan kebijakan dan penyusunan program eliminasi yang komprehensif, sehingga diperlukan sebuah review sistematik untuk memperoleh gambaran terkait faktor sosial budaya, kondisi lingkungan dan faktor-faktor penghambat tercapainya target eliminasi. Hasil review dari 34 jurnal dan 4 laporan tahunan terpublikasi melalui PubMed, Google Scholar, Web of Science, Research Gate, Biomed Central, diketahui bahwa kesadaran masyarakat menjadi kunci mencapai target eliminasi. Hasil review ini dilanjutkan dengan Focus Group Discussion (FGD) untuk menggali pengetahuan dan perilaku masyarakat yang merupakan faktor risiko Schistosomiasis. Pada dasarnya peserta sudah memahami bahwa penggunaan air parit/sungai dan bekerja diwilayah fokus tanpa sepatu boot merupakan faktor risiko infeksi Schistosomiasis, namun mereka belum mampu merubahnya. Hal ini disebabkan sarana air bersih sangat terbatas dan penggunaan sepatu boot dianggap kurang nyaman terutama jika bekerja disawah. Program-program eliminasi saat ini diantaranya penyuluhan rutin terkait upaya preventif, namun belum maksimal dalam mendorong perubahan mindset masyarakat untuk lebih mengutamakan tindakan pencegahan dibandingkan menerima pengobatan. FGD ini berjalan cukup efisien, peserta berperan aktif dan secara terbuka memberikan masukannya. Melalui FGD ini juga mengemuka ide membentuk kader Schistosomiasis tingkat RT di desa-desa endemik dan berpotensi endemik. Hal ini diharapkan dapat lebih mendorong partisipasi masyarakat sehingga cakupan pemeriksaan tinja rutin dapat tercapai, masyarakat mau menggunakan sepatu boot serta menggunakan air bersih yang aman. Penyediaan sarana dan prasarana sanitasi, pembangunan irigasi, senpadan dan penanda wilayah fokus keoang sangat penting untuk mendukung perubahan perilaku masyarakat, ini dapat diwujudkan melalui kerjasama lintas sektor.
\end{abstract}

Kata kunci: Review, Eliminasi, Schistosomiasis, FGD, Sulawesi Tengah

\section{PENDAHULUAN}

Schistosomiasis atau bilharzia menempati rangking ke dua setelah malaria sebagai masalah sosial ekonomi dan kesehatan masyarakat di daerah tropis dan sub tropis (Brunn dan Hansen, 2008 ; Labelo dan Yusna, 2010; Oldeva et.al, 2013). Schistosomiasis merupakan penyakit parasit yang disebabkan oleh trematoda diagenesa dari genus anggota Schistosoma yang umum dikenal sebagai cacing darah (Colley et.al, 2014). Di Indonesia Schistosomiasis hanya ditemukan di Dataran Tinggi Lindu dan Lembah Napu, Sulawesi Tengah, penyakit ini disebabkan cacing Schistosoma japonicum, sedangkan hospes perantaranya keong Oncomelania hupensis lindoensis (Mahmoud, 2011; Sudomo dkk, 2007). Kegiatan pemberantasan Schistosomiasis secara intensif dimulai pada tahun 1982, pengawasan dan pengendalian Schistosomiasis merupakan prioritas masalah kesehatan masyarakat di Sulawesi Tengah. Direktorat Jenderal Pengendalian Penyakit Menular Indonesia memperkirakan bahwa lebih dari 10.000 orang berisiko terinfeksi pada daerah ini. Pemberantasan pada awalnya dititik beratkan pada kegiatan penanganan terhadap manusianya yaitu pegobatan penduduk secara massal yang ditunjang dengan kegiatan penyuluhan, pengadaan sarana kesehatan lingkungan, pemeriksaan tinja penduduk dan survei keong penular dan tikus secara berkala dan rutin (Labelo dan Yusna, 2010). Hasil pemberantasan ini mampu menurunkan prevalensi Schistosomiasis. Selama periode tahun 1982-1988 di Dataran Tinggi Napu terjadi penurunan angka prevalensi dari 33.58\% menjadi $1.51 \%$, namun reinfeksi masih terjadi sehingga prevalensinya masih fluktuatif hingga saat ini (Nurwidayati dan 
Kurniawan, 2007; Rosmini dkk, 2010). Hal ini dapat disebabkan oleh berbagai faktor seperti rantai penularan masih terus berlangsung, kurangnya kesadaran masyarakat, aspek sosial budaya dan ekonomi serta aspek lingkungan. Tingkat prevalensi sangat rendah telah dicapai tetapi upaya lebih lanjut diperlukan untuk eliminasi penyakit tersebut.

Kompleksitas masalah Schistosomiasis memerlukan penagangan komprehensif yang terpadu dan berkesinambungan, sehingga upaya eliminasi harus melibatkan banyak faktor, pengobatan massal tanpa diikuti pemberantasan hospes perantara serta peningkatan kesadaran masyarakat akan sangat mustahil menghilangkan penyakit tersebut dalam waktu lama (Barakat, 2013; Tay et.al, 2011). Berbagai penelitian terkait Schistosomiasis telah banyak dilakukan dan dipublikasikan. Pesatnya laju publikasi literatur dapat menjadi modal dalam mendukung upaya eliminasi Schistosomiasis yang harus menerapkan konsep evidence base dalam kajiannya. Untuk memenuhi tuntutan tersebut metode review sistematik dilanjutkan dengan FGD pada penelitian ini diharapkan dapat menghasilkan tinjauan komprehensif, yang dapat dijadikan landasan bagi praktisi kesehatan, pengambil kebijakan dan instansi terkait dalam menyusun program eliminasi yang dapat diterima dan diaplikasikan pada masyarakat setempat secara terpadu dan berkesinambungan.

\section{METODE STUDI}

Rancangan penelitian ini menggunakan model review sistematik, yang merupakan telaah sistematik untuk menentukan kesimpulan dari beberapa penelitian yang telah dikaji. Review sistematik menolong peneliti menemukan kekonsistenan atau ketidakkonsistenan dalam pengkajian hasil silang dari berbagai hasil penelitian terkait materi kajian (Siswanto, 2010). Penelitian ini diawali dengan pengumpulan literatur terkait Schistosomiasis, dan teridentifikasi 307 melalui pencarian database online yang membahas Schistosomiasis secara umum. Selanjutnya dilakukan penyaringan untuk memperoleh jurnal dan laporan ilmiah yang membahas Schistosomiasis di Indonesia yang telah dipublikasikan. Diperoleh 87 literatur terkait Schistosomiasis, namun hanya 14 jurnal yang terkait upaya eliminasi Schistosomiasis di Sulawesi Tengah, selain jurnal juga digunakan 4 laporan resmi, untuk menunjang pembahasan juga diambil beberapa jurnal Schistosomiasis dari berbagai negara. Rentang waktu literatur yang digunakan adalah 1974-2016. Sumber informasi diambil melalui identifikasi hasil studi yang telah dipublikasikan pada PubMed, Google Scholar, Web of Science, Research Gate, Biomed Central Open Access, serta sumber lainnya.

Beranjak dari hasil review sistematik dilakukan Focus Group Discussion (FGD), hal ini dimaksudkan untuk memperoleh informasi dari berbagai latar belakang pengalaman tertentu sehingga diperoleh perspektif yang lebih komprehensif. FGD ini dilakukan pada 3 desa yang merupakan daerah fokus yaitu Desa Anca, Desa Kaduwaa, dan Desa Mekarsari. Peserta FGD berjumlah 11 orang dengan rentang usia 18-50 tahun. Penanggung jawab P2M Puskesmas setempat bertindak sebagai moderator, peneliti pertama sebagai observer dan peneliti kedua sebagai notulen, 1 tetua desa, 1 orang pengelola Laboratorium Schistosomiasis, 6 orang masyarakat penderita atau pernah menderita Schistosomiasis sebagai peserta. FGD ini dilakukan untuk menentukan upaya eliminasi yang dibutuhkan dan mampu diaplikasikan masyarakat setempat. FGD dilaksanakan di balai desa selama 60-90 menit (pukul 19.30 sampai selesai). FGD dimulai dengan perkenalan, pemaparan terkait tujuan kegiatan dan manfaatnya, dilanjutnya dengan menggali pengalaman dan persepsi peserta terkait kejadian Schistosomiasis, pada tahap akhir peserta diminta memberikan masukan terkait program-program eliminasi Schistosomiasis baik yang sementara berjalan, maupun harapan kedepannya. 


\section{HASIL PENELITIAN}

Berdasarkan kajian literatur ditemukan bahwa aspek sosial budaya terutama tingkat pengetahuan, perilaku dan kesadaran masyarakat merupakan faktor kunci eliminasi Schistosomiasis (Mwanga, 2005). Beranjak dari sini maka peneliti berusaha menggali pengalaman dan persepsi masyarakat terkait kejadian Schistosomiasis melalui FGD pada 3 desa, yang dimulai dari Desa Anca, kemudian Desa Kaduwaa, dan Desa Mekarsari. Moderator membuka FGD (10 menit), dalam sesi ini dilakukan perkenalan, mejelaskan tujuan pertemuan, menjelaskan alasan mengundang peserta dan meminta mereka memberikan pendapat secara jujur dan terbuka, serta menegaskan kerahasiaan informasi yang disampaikan peserta dalam diskusi. Diskusi dilanjutkan dengan memberikan presentase singkat tentang potret kejadian Schistosomiasis di desa setempat. Kemudia moderator memberikan pertanyaan terkait kebiasaan-kebiasaan apa saja yang dapat menyebabkan seseorang terinfeksi dan bagaimana gejala awal Schistosomiasis. Setiap peserta diminta menuliskan jawabannya pada selembar kertas. Jawaban peserta penderita atau yang pernah menderita Schistosomiasis secara rinci pada tabel 1.

Tabel 1. Pengetahuan dan Perilaku Masyarakat Daerah Endemik Schistosomiasis

\begin{tabular}{|c|c|c|c|c|}
\hline \multirow[t]{2}{*}{ Atribut } & \multirow[t]{2}{*}{ Pilihan } & \multicolumn{3}{|c|}{ Catatan Fasilitator } \\
\hline & & Desa Anca & Desa Kaduuwa & Desa Mekarsari \\
\hline $\begin{array}{l}\text { Pemanfaatan air } \\
\text { bersih }\end{array}$ & $\begin{array}{l}\text { Parit } \\
\text { Sungai } \\
\text { Pipa } \\
\text { Sumur gali } \\
\text { PDAM }\end{array}$ & $\begin{array}{l}\text { Sumber air bersih dari } \\
\text { parit dan sungai, untuk } \\
\text { keperluan memasak dan } \\
\text { minum mengambil air } \\
\text { pada bak umum yang } \\
\text { disediakan pemerintah }\end{array}$ & $\begin{array}{l}\text { Sumber air bersih dari } \\
\text { parit, untuk keperluan } \\
\text { memasak dan minum } \\
\text { mengambil air pada bak } \\
\text { umum yang disediakan } \\
\text { pemerintah }\end{array}$ & $\begin{array}{l}2 \text { peserta } \\
\text { meggunakan parit dan } \\
\text { sungai sebagai } \\
\text { sumber air bersih dan } \\
\text { air minum, } 4 \text { peserta } \\
\text { menggunakan sumur } \\
\text { gali }\end{array}$ \\
\hline $\begin{array}{l}\text { Bekerja disekitar } \\
\text { wilayah fokus } \\
\text { keong }\end{array}$ & $\begin{array}{l}\text { Kebun } \\
\text { Sawah } \\
\text { Berburu }\end{array}$ & $\begin{array}{l}\text { Peserta memiliki sawah } \\
\text { dan kebun cokelat yang } \\
\text { berada disekitar } \\
\text { wilayah fokus. Saat } \\
\text { bekerja enggan } \\
\text { menggunakan sepatu } \\
\text { boot }\end{array}$ & $\begin{array}{l}5 \text { peserta memiliki } \\
\text { sawah, } 1 \text { peserta } \\
\text { memiliki kebun disekitar } \\
\text { wilayah fokus. Saat } \\
\text { bekerja enggan } \\
\text { menggunakan sepatu } \\
\text { boot }\end{array}$ & $\begin{array}{l}\text { Peserta memiliki } \\
\text { kebun sayur disekitar } \\
\text { wilayah fokus. Saat } \\
\text { bekerja enggan } \\
\text { menggunakan sepatu } \\
\text { boot }\end{array}$ \\
\hline $\begin{array}{l}\text { Gejala awal } \\
\text { Schistosomiasis }\end{array}$ & $\begin{array}{l}\text { Ruam/gatal- } \\
\text { gatal } \\
\text { Diare, mual, } \\
\text { demam, kram } \\
\text { perut }\end{array}$ & $\begin{array}{l}4 \text { peserta mengetahui } \\
\text { terinfeksi setelah } \\
\text { dilakukan pemeriksaan } \\
\text { tinja rutin, sedangkan } 2 \\
\text { diantaranya } \\
\text { memeriksakan diri } \\
\text { setelah mengalami } \\
\text { gejala demam dan kram } \\
\text { perut }\end{array}$ & $\begin{array}{l}\text { Peserta mengetahui } \\
\text { gejala awal } \\
\text { Schistosomiasis berupa } \\
\text { ruam kulit disertai rasa } \\
\text { gatal selama beberapa } \\
\text { hari, namun diabaikan } \\
\text { hingga rasa gatal dan } \\
\text { ruam hilang dengan } \\
\text { sendirinya }\end{array}$ & $\begin{array}{l}\text { Peserta mengetahui } \\
\text { terinfeksi setelah } \\
\text { dilakukan } \\
\text { pemeriksaan tinja } \\
\text { rutin }\end{array}$ \\
\hline
\end{tabular}

FGD dilanjutkan dengan 3 pertanyaan kunci untuk mengetahui program-program eliminasi yang saat ini dilakukan dan bagaimana harapan peserta terhadap program-program selanjutnya. Hasil diskusi secara rinci pada tabel 2. 
Tabel 2 Program-program Eliminasi Schistosomiasis pada Daerah Endemik

\begin{tabular}{|c|c|c|c|}
\hline \multirow[t]{2}{*}{ Atribut } & \multicolumn{3}{|c|}{ Catatan Fasilitator } \\
\hline & Desa Anca & Desa Kaduuwa & Desa Mekarsari \\
\hline $\begin{array}{l}\text { Apa saja program elminasi } \\
\text { yang dilaksanakan saat ini? }\end{array}$ & \multicolumn{3}{|c|}{$\begin{array}{l}\text { Program MDA (pemberian Praziquantel) berlangsung sejak lama, pemeriksaan } \\
\text { tinja ruitn (per } 6 \text { bulan), penyuluhan PHBS, pembagian sepatu boot. Juga } \\
\text { dilakukan survei keong dan hospes perantara lainnya dan pemasangan penanda } \\
\text { wilayah fokus }\end{array}$} \\
\hline \multirow{4}{*}{$\begin{array}{l}\text { Apakah program ini dapat } \\
\text { diterima/dilaksanakan } \\
\text { masyarakat? } \\
\text { Follow-up : Jika tidak } \\
\text { dapat diterima atau } \\
\text { dilaksanakan, megapa? }\end{array}$} & \multicolumn{3}{|c|}{$\begin{array}{l}\text { Program MDA masih efisien mengobati penderita hingga } 100 \% \text {, namun kurang } \\
\text { maksimal jika cakupan pemeriksaan tinja rutin }<80 \% \text {. Dinas Kesehatan telah } \\
\text { mengujicoba obat alternatif (pucuk daun pepolo), namun memakan waktu lama dan } \\
\text { harus konsisten. }\end{array}$} \\
\hline & \multicolumn{3}{|c|}{$\begin{array}{l}\text { Penyuluhan PHBS kurang efisien karena tidak disertai pembangunan sarana } \\
\text { sanitasi yang memadai, seperti penyediaan air bersih dari pipa masih rendah }\end{array}$} \\
\hline & $\begin{array}{l}\text { Penggunaan sepatu } \\
\text { boot sulit, terutama } \\
\text { untuk kesawah (lumpur } \\
\text { tinggi) }\end{array}$ & $\begin{array}{l}\text { Penggunaan sepatu boot } \\
\text { kurang nyaman (belum } \\
\text { terbiasa), dan sulit } \\
\text { digunakan di sawah } \\
\text { (lumpur tinggi) }\end{array}$ & $\begin{array}{l}\text { Penggunaan sepatu boot } \\
\text { di kebun cukup efisien } \\
\text { menghindari infeksi } \\
\text { parasite Schistosoma }\end{array}$ \\
\hline & $\begin{array}{l}\text { Survei keong dan } \\
\text { hospes perantara saja } \\
\text { tidak cukup, diperlukan } \\
\text { upaya lain untuk } \\
\text { pemetaan wilayah fokus } \\
\text { dan wilayah berpotensi } \\
\text { sebagai fokus baru }\end{array}$ & $\begin{array}{l}\text { Pemberantasan wilayah } \\
\text { fokus sering terhambat } \\
\text { karena hujan dari lereng } \\
\text { membawa keong } \\
\text { menyebar membentuk } \\
\text { wilayah fokus baru }\end{array}$ & $\begin{array}{l}\text { Survei keong tidak } \\
\text { terlalu penting dan } \\
\text { dampaknya tidak besar } \\
\text { untuk mencegah } \\
\text { penularan } \\
\text { Schistosomiasis }\end{array}$ \\
\hline $\begin{array}{l}\text { Bagaimana seharusnya } \\
\text { program eliminasi } \\
\text { Schistosomiasis dilakukan? }\end{array}$ & $\begin{array}{l}\text { Utamakan pencehagan, } \\
\text { wajibkan pemeriksaan } \\
\text { tinja rutin dan sediakan } \\
\text { akses air bersih melalui } \\
\text { pipa, bekerja disawah } \\
\text { saat siang hari }\end{array}$ & $\begin{array}{l}\text { Membangun sempadan di } \\
\text { sekitar lereng bukit } \\
\text { sehingga tidak terbentuk } \\
\text { fokus baru saat hujan dan } \\
\text { memasang penanda } \\
\text { wilayah fokus lebih besar } \\
\text { dan mudah dilihat }\end{array}$ & $\begin{array}{l}\text { Membangun sempadan } \\
\text { di sekitar lereng bukit } \\
\text { sehingga tidak } \\
\text { terbentuk fokus baru } \\
\text { saat hujan }\end{array}$ \\
\hline $\begin{array}{l}\text { Diperlukan kerja sama } \\
\text { lintas sektor? }\end{array}$ & \multicolumn{3}{|l|}{ Sangat diperlukan } \\
\hline $\begin{array}{l}\text { Follow-up: Siapakah yang } \\
\text { harus berperan aktif dalam } \\
\text { pelaksanaan program } \\
\text { eliminasi Schistosomiasis? }\end{array}$ & \multicolumn{3}{|c|}{$\begin{array}{l}\text { Puskesmas, Laboratorium Schistosomiasis, Dinas Kehutanan, Dinas Pertanian, } \\
\text { Dinas PU, Konsultan Desa Tertinggal dan masyarakat setempat }\end{array}$} \\
\hline
\end{tabular}

FGD diakhiri dengan pertanyaan penutup "apakah ada cara khusus untuk memicu partisipasi masyarakat yang merupakan kunci keberhasilan program eliminasi?”. Hasil diskusi dari tiga desa mengemuka beberapa program yang dianggap mampu meningkatkan animo masyarakat, seperti membentuk kader Schistosomiasis dari masyarakat pada tingkat RT, memberikan reward bagi kader saat tidak ada masyarakat terinfeksi Schistosomiasis pada wilayah kerjanya saat dilakukan pemeriksaan tinja rutin, dan memberikan reward bagi kader yang mampu mengajak $>80 \%$ masyarakat dalam wilayah kerjanya berpartisipasi dalam pemeriksaan tinja rutin. Di desa Mekarsari bahkan menyarankan pemilihan kader terpavorit tahunan. 


\section{PEMBAHASAN}

Upaya eliminasi saat ini yang berfokus pada pemeriksaan tinja rutin dan pengobatan masyarakat terinfeksi tidak akan maksimal jika perilaku masyarakat tidak berubah (WHO, 2002). Masyarakat di Desa Anca dan Kaduwaa memanfaatkan air parit dan air sungai sebagai sumber air bersih sehingga berpeluang terinfeksi, dimana kita ketahui pemanfaatan air parit sebagai sumber air bersih merupakan faktor risiko terjadinya Schistosomiasis dengan OR 2,31 (Hariyanto, 2006) dan OR 3,67 (Labelo dan Yusna, 2010). Sedangkan di Desa Mekarsari meskipun sebagian besar menggunakan air sumur namun lokasi kebun yang berada disekitar wilayah fokus dapat menyebabkan infeksi atau reinfeksi terutama jika saat bekerja tidak menggunakan alat pelindung diri seperti sepatu boot. Sebagaimana kita ketahui habitat keong perantara umumnya pada area persawahan, kebun, padang rumput, dan hutan lindung (Hafsah, 2013).

Upaya-upaya preventif terhadap Schistosomiasis pada 3 desa endemik juga telah dilakukan melalui berbagai upaya seperti penyuluhan rutin dari pihak P2M puskesmas setempat. Materi penyuluhan sudah menjelaskan terkait cara-cara penularan dan cara pemberantasan penyakit, dan pada dasarnya masyarakat telah mengetahuinya. Namun sayangnya, terkadang pengetahuan yang baik tidak serta merta diikuti dengan perubahan perilaku ke arah yang lebih baik juga. Hal ini sejalan dengan penelitian Ningsi dkk (2011), dimana masyarakat di Dataran Tinggi Lindu mengetahui secara sederhana mekanisme penularan Schistosomiasis dan tindakan pencegahan standar, namun masyarakat tetap melakukan kebiasaan memanfaatkan air sungai yang mengandung parasit Schistosoma untuk keperluan MCK (Mandi, Cuci, Kakus). Masyarakat juga mengetahui gejala-gejala awal infeksi Schistosomiasis seperti ruam disertai rasa gatal 4-8 minggu namun diabaikan, inisiatif untuk memeriksakan diri setelah mengalami gejala mual, pusing, lemas, kram perut atau demam naik turun. Pada fase ini, telur cacing $S$. japonicum telah menetas (Fiqueiredo, 2012), dan segera akan diikuti dengan sirosis hati jika tidak segera diobati (Terer, 2013). Sebagian besar penderita bahkan baru menyadari infeksi setelah pemeriksaan tinja rutin yang dilakukan setiap 6 bulan oleh dinas kesehatan bekerjasama dengan Laboratorium Schistosomiasis Napu.

Masyarakat menyadari adanya potensi infeksi Schistosomiasis namun masih enggan memikirkan cara pencegahan pribadi agar tidak tertular, dan hanya mengandalkan pengobatan medis dengan Praziquantel (Pzq) karena dianggap efektif mematikan cacing. Hal ini menjadi tantangan besar bagi Pemerintah, karena memberdayakan masyarakat dimulai dengan perubahan mindset, mendahulukan pencegahan dibandingkan pengobatan. Program Mass Drug Administration (pemberian Praziquantel) dan program pengendalian lainnya seperti survei keong dan hospes perantara lain telah berlangsung sejak tahun 1982 (WHO, 2002), termasuk pada ketiga desa ini. Pemeriksaan tinja rutin dilakukan per 6 bulan untuk menjaring penderita Schistosomiasis, masyarakat yang fecesnya positif mengandung telur cacing akan diberikan Pzq dengan dosis $60 \mathrm{mg} / \mathrm{kg} \mathrm{BB}$, sedangkan pada anak-anak $<10$ tahun dosis dikurangi $40 \mathrm{mg} / \mathrm{kg} \mathrm{BB}$. Pzq masih menjadi pilihan utama pengobatan dengan efektivitas tinggi dan efek samping ringan hingga menengah seperti mual, mengantuk dan terkadang sakit perut. Hal ini sejalan dengan penelitian Anis dkk (2016), pemberian Pzq $60 \mathrm{mg} / \mathrm{kg}$ BB pada 80 penderita Schistosomiasis di Kabupaten Napu dalam 3 minggu tidak ditemukan lagi telur cacing S. japonicum. Namun Pzq tidak bisa diberikan pada ibu hamil, pengobatan harus ditunda hingga selesai melahirkan jika terjadi infeksi. Pengadaan obat juga memerlukan waktu agak lama karena Pzq hanya didistribusikan WHO melalui kementerian kesehatan pusat dan tidak dapat diproduksi sendiri. Prosedur pengadaan obat rumit sehingga pernah terjadi kekosongan obat sedangkan banyak 
masyarakat positif terinfeksi. Hal ini yang mendorong dinas kesehatan provinsi (2015) melakukan riset untuk menemukan obat alternatif, salah satu yang telah diuji coba adalah pemberian pucuk daun pepolo (Bischovia japonica) $\pm 10 \mathrm{~cm}$ selama 14 hari pagi dan sore hari, pengujian menunjukkan adanya penurunan jumlah telur secara signifikan. Namun pengobatan ini dirasa sulit karena rasa daun pepolo yang menyengat di tenggorokan, serta harus dikomsumsi secara rutin pagi dan sore hari selama 14 hari tanpa putus. Masyarakat berpendapat bahwa pemberian Pzq lebih efisien, namun hal ini harus didukung dengan peningkatan cakupan pemeriksaan tinja rutin, target cakupan $>80 \%$ hingga saat ini belum tercapai. Peningkatan cakupan pemeriksaan tinja rutin mutlak dilakukan, mengingat identifikasi infeksi hanya mungkin dilakukan melalui pemeriksaan tinja positif. Jika memungkinkan, cakupan pemeriksaan tinja rutin diwajibkan kepada masyarakat terutama pada desa-desa endemik.

Peningkatan kesadaran masyarakat dan kerjasama lintas seektor harus dilakukan terutama Dinas Kehutanan, Dinas Pertanian, Dinas PU, Konsultan Desa Tertinggal dan masyarakat setempat. Selain upaya-upaya promotif dari petugas kesehatan setempat, diperlukan penyediaan sarana air bersih yang memadai, lebih diutamakan sistem pipa ututk mengurangi potensi kontaminasi. Disamping itu pembangunan sempadan disekitar lereng bukit untuk menghindari penyebaran keong saat hujan harus dilakukan, sebab penyebaran keong akan menciptakan wilayah fokus baru sehingga penyebaran penyakit semakin luas. Membatasi wilayah fokus akan memperkecil potensi penyebaran parasite Schistosoma baik melalui keong, maupun melalui tikus dan hewan ternak lainnya. Disamping itu pemasangan penanda wilayah fokus juga disarankan peserta, adanya penanda dapat menjadi peringatan dini untuk tidak mendekati atau beraktifitas diwilayah tersebut. Saat ini penanda wilayah fokus telah dipasang, namun tanda sulit terlihat dari jauh sehingga masyarakat terlambat menyadari telah berada di wilayah fokus. Disamping itu keberadaan wilayah fokus baru dan wilayah berpotensi sebagai fokus baru juga harus diantisipasi. Pemanfaatan GIS dapat menjadi alternatif dalam pemetaan wilayah fokus baru dan wilayah berpotensi, sebagaimana dikemukakan Mujiyanto dan Jastal (2014).

Semua program yang dilakukan pemerintah memerlukan dukungan dan partisipasi masyarakat sebagai subyek utamanya. Diskusi yang dilakukan pada tiga desa endemik, mengemuka beberapa program yang dianggap mampu meningkatkan animo masyarakat, yaitu membentuk kader Schistosomiasis dari masyarakat pada tingkat RT, kader dipilih dari masyarakat terutama yang pernah mengalami infeksi Schistosomiasis. Kader bertugas secara aktif mengajak masyarakat untuk menerapkan upaya-upaya pencegahan individu, seperti menggunakan air bersih bukan dari parit atau sungai, meminta anak-anak untuk tidak bermain disekitar parit atau sungai, saat bekerja dikebun gunakan sepatu boot, saat bekerja disawah lakukan pada siang hari. Pembentukan kader pada tingkat RT diharapkan dapat lebih mendekatkan upaya-upaya preventif pada masyarakat. Melibatkan masyarakat secara langsung dalam penyusunan dan pelaksanaan program akan mendorong partisipasi masyarakat (Adamson dan Bromiley, 2008).

Untuk memotivasi kader, maka dinas kesehatan diharapkan dapat memberikan reward bagi kader apabila tidak ada masyarakat terinfeksi Schistosomiasis pada wilayah kerjanya saat dilakukan pemeriksaan tinja rutin dan memberikan reward bagi kader yang mampu mengajak $>80 \%$ masyarakat dalam wilayah kerjanya berpartisipasi dalam pemeriksaan tinja rutin. Bahkan jika memungkinkan dapat dilakukan pemilihan kader terpavorit tahunan di setiap desa. Pemberian reward cukup efektif dalam meningkatkan motivasi kerja seseorang, teori motivasi eksternal mengemukakan seseorang akan bergerak atau mengambil tindakan apabila ada insentif yang akan didapatkan. 


\section{KESIMPULAN DAN SARAN}

Pada tiga desa endemik telah banyak program yang dilakukan namun belum maksimal karena rendahnya partisipasi masyarakat. Perubahan mindset untuk lebih mengutamakan tindakan pencegahan pribadi agar tidak terinfeksi sangat diperlukan. Melalui FGD disimpulkan bahwa mendorong partisipasi masyarakat menjadi kunci untuk meningkatkan cakupan pemeriksaan tinja rutin, penggunaan sepatu boot dan pemanfaatan air bersih yang aman. Diputuskan bahwa membentuk kader Schistosomiasis pada tingkat RT di setiap desa endemik merupakan alternatif terbaik. Disamping itu penyediaan sarana dan prasarana sanitasi, pembangunan irigasi dan senpadan serta pemasangan penanda wilayah fokus penting dalam menunjang perubahan perilaku masyarakat, kerjasama lintas sektor terutama melibatkan dinas kehutanan, dinas pertanian dan dinas PU mutlak dilakukan.

\section{REFERENSI}

Adamson, Dave dan Bromiley Richard. 2008. Community Empowerment in Practice. Joseph Rowntree Foundation: York Publishing Services Ltd, 64 Halfield Road.

Anis N, Triwibowo A.G, Phetisya P.R.S dan Riski. 2016. Kerentanan Shistosoma Japonicum Terhadap Praziquantel di Napu dan Lindu Sulawesi Tengah. Balai Litbang P2B2 Donggala Sulawesi Tengah.

Barakat, Rashida M.R. 2013. Epidemiology of Schistosomiasis in Egypt : Travel Through Time (Review). Journal of Advanced Research, 4, Issue 5 (425-432).

Brunn, Birgitte dan Hansen. J.A. 2008. The Social Context of Schistosomiasis and Its Control. Special Program For Research and Training in Tropical Disease (TDR). UNICEF.

Colley DG, Bustinduy AL, Secor WE dan King CH. 2014. Human Schistosomiasis. The Lancet Artikel PubMed, S0140-6736(13)61949-2.

Fiqueiredo S, M Betson, Atuhaire A, Arinaitwe M, Navaratnam AM, NB Kabatereine, Q Bickle dan JR Stothard. 2012. Performance and Safety of Praziquantel for Treatment of Intestinal Schistosomiasis in Infants and Preschool Children. PLOS Neglected Tropical Disease, 6 (10) $e 1864$.

Hafsah. 2013. Karakteristik Habitat dan Morfolog Siput Ongcomelania hupensis lindoesis Sebagai Hewan Reservoir dalam Penularan Schistosomiasis Pada Manusia dan Ternak di Taman Nasional Lore Lindu . Jurnal Manusia dan Lingkungan, 20 No.2 (144-152).

Kementerian Kesehatan RI. 2015. Observasi Klinik Herbal Pucuk Pepolo (Biscovia javanica) sebagai Pengobatan Alternatif Schistosomiasis.

Labelo, D.J dan Yusna, H.I. 2011. The Community Behaviour of Productive Age on The Incidence of Schistosomiasis in Maholo Villages Napu Valley Poso Distric Central Sulawesi on 2010-2011. Public Health Faculty, Indonesia University : Jakarta.

Mahmoud, Adel AF. 2001. Schistosomiasis : Setting the Stage. Ebook Online : http://www.worldscientific.com/worldscibooks/10.1142/p126.

Mwanga, JR. 2005. Perceptions and Practices on Schistosomiasis Among Communities in Ukerewe District Tanzania. Tanzania Health Research Bulletin, 7 No. 2.

Mujiyanto dan Jastal. 2014. Pemanfaatan Peginderaan Jauh dan SIG dalam Identifikasi Fokus Baru Schistosomiasis di Dataran Tinggi Bada Kabupaten Poso Sulawesi Tengah. Seminar Nasional Penginderaan Jauh, Jakarta, 205-214. 
Ningsih, Sani.Y dan Hijjang P. 2011. Pengetahuan dan Perilaku Kesehatan Masyarakat Lindu Terkait Kejadian Schistosomiasis di Kabupaten Sigi Sulawesi Tengah. Balai Litbang P2B2 Kabupaten Donggala

Nurwidayati, Anis dan Kurniawan A. 2007. Koleksi Referensi Schistosomiasis di Dataran Tinggi Lindu Kabupaten Donggala Sulawesi Tengah. Jurnal Vektor Penyakit, 1 Nomor 1. ISSN : 1978-3647.

Olveda D.U, Yueseng, Olveda R.M, Lam A.K, Chaou T, Harn D.A, William G.M, Gray D.J, Ross A.G.P. 2013. Bilharzia : Pathology, Diagnosis, Management and Control. Tropical Medicine and Surgery, 1 No. 4. ISSN : 2329-9088.

Rosmini, Soeyoko dan Sumarni S. 2010. The Transmission of Schistosomiasis in Dodolo and Mekarsari Villages of Napu Hihgland Central Sulawesi. Media Litbang Kesehatan, XX Nomor 3.

Siswanto. 2010. Systematic Review Sebagai Metode Penelitian untuk Mensintesis Hasil-hasil Penelitian. Pusat Penelitian dan Pengembangan Sistem Kebijakan Kesehatan. Kementerian Kesehatan.

Sudomo, Mohammad dan Carney W Patrick. 1974. Precontrol Investigation of Schistosomiasis in Central Sulawesi. Health Studies Indonesia, II No. 2.

Tay S.C.K, Amnkwa R dan Gbedema S.Y. 2011. Prevalence of Schistosomiasis Haematobium Infection in Ghana : A Restrocpective Case Study in Kumasi. International Journal of Parasitology Research, 3, Nomor 2 (PP 48-52).

Terer CC, Bustinduy AL, Magtanong RV, Muhoho N, Mungai PL, Muchiri EM, Kitron U, King $\mathrm{CH}$ dan Mutuku FM. 2013. Evaluation of Health-related Quality of Life of Children Schistosoma haematobium Endemic Communities in Kenya: A Cross Sectional Study. PLOS Neglected Tropical Disease, 7, Issue 3 (e2106).

World Health Organization Expert Committe. 2002. Report Series : Prevention and Control of Schistosomiasis and Soil-Transmitted Helminthiasis. Geneva. 